\title{
Using Flipped Classroom Technique on Online Teaching Platform during COVID-19
}

\author{
Christ Helan I 1, Dr.K.Anbazhagan ${ }^{2}$ \\ ${ }^{1}$ Research Scholar, SRM Institute Of Science And Technology \\ ${ }^{2}$ Research Supervisor, SRM Institute Of Science And Technology \\ ${ }^{1}$ christhi@srmist.edu.in
}

\begin{abstract}
Owing to the spread of COVID-19, in order to maintain teaching learning during this disruption, the educational system is shifted to online teaching. This article is aimed to analyse the recent trends and the need for revision in the material. The impact of flipped teaching method on students and challenges were analysed in this research to investigate the pre-existing studies, technological tools and the online platform. The quasi-experimental method is used to analyse the implication of FL technique. The students of Engineering and Technology were selected as samples. On the whole 128 students from two sections have used the teaching of Flipped learning approach for the experimental group and 67 students from one section have been using traditional lectures for the control group. In the students' perceptions, flipped learning is included with questionnaires of open-ended and close-ended. The results have shown flipped learning has better performance. They have become conscious of a unique set of affordances and restrictions; they have shown more attention to flipped learning. It is found that different departments were using the FL approach and online technological sources have been used for online practice. The flipped classroom has brought positive results on students' learning activities like achievements, interactions, motivations, and so on. Poor quality of video and untrained lecturer has been addressed as a great challenge in inculcating the flipped classroom environment.
\end{abstract}

Key words:

Flipped Learning, Educational system, Teaching-learning activities, Online teaching

Article Received: 10 August 2020, Revised: 25 October 2020, Accepted: 18 November 2020

\section{Introduction}

Learning wouldn't easily understandable from the lecturer to the student (Touchton, M (2015) ; Wang, S., \& Heffernan, 2009), rather than critical thinking skills, problem-solving skills, and selfevaluation have been involved (Lee \& Lai, 2017; Hattie \& Donoghue, 2016). These skills are most wanted for everlasting success (Rateau et al 2015). Constructionism and social constructivism are theories of modern learning, and students have become more interested of learning through the social interaction. However, the analysis had shown that the teaching/learning was proceeding in the traditional way of methods, even though a lack of critical thinking of learners would develop (Rateau et al., 2015). Advanced pedagogy and emerging technologies would unstable because of the traditional way of practicing. The current research has been focused on flipped learning approach than active traditional teaching strategy because it has inspired and made the learners build their own understandings in in-class. Quasiexperimental has suggested flipped classroom is a presentation to instructive innovation (IET-112) course within the division of Instructive
Innovation (DET) at the college of fundamental instruction and Kuwait's Open Specialist for Connected Instruction and Preparing (PAAET).uggested Several technology tools like computers, laptops, smart phones can easily access and gather more information on this twenty-first century (Fu, 2013). Nowadays students could mostly use this sort of technology and they can easily interact with their friends, instructors, and it is possible to acquire distant learning (Fisher, 2009). Including several materials are available on websites for their free learning. Richter and McPherson (2012) argues that in today's digital world, each student can access their own free learning on the internet for their convenience. The use of traditional learning methods would have been focused on lecturers' knowledge (Wang \& Heffernan, 2009). The traditional classrooms would have been moved to current technology and students could easily study everywhere. The replacement of the blackboard to online lectures has shown the positive impact and growth of technology (Evans, 2011). The usage of technology in education field could increase the relationship of social interactions, sharing ideas, and so on. In other hand, the different kinds of 
technology can make learners study in various locations. The new method of learning has influenced the education of students' independence. Technology plays a vital role in education where students and instructors can get updated themselves. According to Horizon's report flipped classroom has been highlighted technology and that should be used at the college levels (Johnson et al., 2014). So, the authors believed that the flipped classroom has been initative in the journals.

\section{Literature Review}

Hwang, Gwo-Jen et al (2015) has introduced characteristics, educational objectives of flipped learning; the features of wireless and mobile communication technologies have been approached in the flipped classroom to develop the FL activities for students and educators and it has helped the students to learn unfitnesslessly across texts.

Roach, Travis (2014) "Partially-flipped" class has been enrolled in the course of microeconomics over one semester, including the students 'opinion towards flipped learning. It found that student groups have positively responded to flipped learning.

Hao, Yungwei (2016) The results have shown that the students haven't prepared for the flipped learning approach. Above $60 \%$ of students have only understood the benefits of the flipped classroom. Only $38 \%$ of students believed in traditional teaching methods

Lo, Chung Kwan, and Khe Foon Hew (2017) This paper is about to add an overview of the flipped classroom for K12 students. Flipped learning activities, students' achievements, students' attitudes of flipped classroom have been analyzed in the Fifteen journal publication of K12. The research shows the kind of pre-school and in-class have been provided in the additional videos.

Akçayır, Gökçe, and Murat Akçayır (2018) The literature of the flipped classroom have been examined and it was challenging for both students and lecturer, Social Sciences Citation Indexed journals have been observed to the Web of Science and the total number of 71 articles have been selected for review. The results have believed that the advantage of the flipped classroom has developed the students' performs. Also have found many other summonses in the
FL. Several other advantages of flipped classrooms have been discussed in detail.

In the current study, the research confirmed that student' positive achievements, good performance happened throughout the tests. This analysis has revealed the flip-class has increased the level of motivation.

\section{Flipped Classroom in an online Classroom}

In consideration to the sudden shift from traditional classroom to online teaching during COVID-19 issue, the adoption of online teaching has emerged. The incorporation of flipped learning in online teaching platform enhances the learners to adopt learning easily. Flipped learning (FL) is the recent advancement technique involved in teaching. The FL is the alternative method where students get an opportunity to engage with teachers and fellow mates, where the communication among them occurs which is referred to as the traditional way of teaching in a classroom. Unlike traditional learning, FL is computer-based learning by which students can get access to studying anywhere at any place and anytime. Access to the study material is available to them at any time. The content comes in a digital video format they could listen to the study material more often [20]. The concept of FL was first introduced by Salman Khan. Who laid the founding stone of flipped learning in 2006 and founder of a non-profit organization called the "Khan Academy" The FL gives more understanding of the concepts for the students, and the learning the basics in home students engage with the teachers and classmates so easily. The modern technology has made the FL approach to reach easily to everyone with online and digital video recordings apps. This concept concentrates more on students which have become more student-centric. It also improves student's interest in concepts that they like, and more time can be engaged on it depending upon the students learning interest of a particular subject, and it promotes the creative side of the students. This paper enquires the learning efficiency of flipped classroom through online teaching under COVID19.

\section{Methodology involved in this Research paper}

\subsection{Research Strategy and Design.}

This research is carried out through the quantitative research approach "Content 
Analysis". The concept of content analysis is the investigation of the content and understanding of the approach, theme, and the ideas involved in bringing the content and interpretation of the objective of the content used in a particular concept. This method can be used to analyse the content in the video, text, audio, and online content [24].

This research tries to interpret the content of twenty refereed journals that used the concept of Flipped classroom research. For this method articles published from 2013-2015 these 3 years thesis based on Flipped learning is considered as the main content for analysing.

Content Analysis (CA) to Creswell (2012) [11] was referred to as analysing content in text, pictures, and antiquity (ornaments made by a person). CA is the analysis of the content of the published article, reviewing the article, explaining the content of the article with the development of content, and understanding the objective of the content clearly [25]. A content analysis is sometimes described as the content with the same idea and theme can easily be identified and compared for the further study of the particular concept in the future[26]. A content analysis in the distance education method has been utilized to identify the current trends by using journals published between 2009 to 2013 considering 860 journals and founded that content analysis is mostly used in education [27].

In this study, the analysis was made on the keyword used, the concept of the study, the type of research design used in the study, the data collection method, the reference authors used, and the target group or audience used in the study.

Talbert, R. (2014) [28] tried to understand the concept of content analysis by examining the content of several articles published between the years 2005-2014. The findings and the procedure involved in the study which includes the purpose of the study and understanding its essence and the ideas and information used was analyzed. This study was based on the idea and nature of [1-3]. This content analysis involved more time and the procedure of the findings was lengthy.

Content analysis [4-7] is stated as a steady process that considers all the steps involved in the study. Journals published in the form year 2013-2015 were taken into consideration for this process of analyzing. The outcomes of this study which involves further research to be carried out on the concept of Flipped classroom research and must be included in the further literature as a reference in the later period.

When compared to the other research groups and study this EG and CG were considered as the best approach for this research. This remarkable method was applied on audience for estimating the impact of the study.

\subsection{Questionnaire and Procedure Involved in the Research}

The method and the questionnaire involved in this research paper are detailed in the tabulation

\begin{tabular}{|l|l|}
\hline Method & Research Question \\
\hline t-test & $\begin{array}{l}\text { Is there a valid difference } \\
\text { in the learning outcomes } \\
\text { when a FL is used, } \\
\text { compared to traditional } \\
\text { approach? }\end{array}$ \\
\hline $\begin{array}{l}\text { Questionnaire- } \\
\text { Descriptive,Statistics, } \\
\begin{array}{l}\text { Qualitative open- } \\
\text { ended, Thematic } \\
\text { Analysis }\end{array}\end{array}$ & $\begin{array}{l}\text { How do students } \\
\text { perceive the use of the } \\
\text { FL model in terms of its } \\
\text { usefulness in learning? }\end{array}$ \\
\hline
\end{tabular}

There are 2 methods involved in determining the result of this study they are: testing to understand the outcome of the FL and testing done by giving questions to student's who have knowledge on FL.

\subsection{Sampling taken for this Research}

This research was conducted through examining the twenty research articles published between the years 2013 to 2015.

These journals were examined through the following method as follows:

1) Focusing on FL Research

2) Journals with a well-known database of SSCI.

3) The Journals Published between 2013-2015 was taken into consideration.

4) Different functional areas of the study were focused on.

The twenty journals were taken from several online websites they are Science Direct, Tailor and Francis, Springer link, etc.

On the whole ten articles were reviewed from professional journals and published in SSCI: IRROD, ETR\&D, I\&HE, C\&E, JNE, JS, CALL, EPM, BMC. 
The 10 Journals:

\begin{tabular}{|l|l|l|}
\hline SL.NO & Abbreviation & Explanation \\
\hline 1 & SSCI & $\begin{array}{l}\text { Social Sciences } \\
\text { Citation Index }\end{array}$ \\
\hline 2 & I\&HE & $\begin{array}{l}\text { The Internet and } \\
\text { Higher Education }\end{array}$ \\
\hline 3 & IRROD & $\begin{array}{l}\text { The International } \\
\text { Review of Research in } \\
\text { Open and Distributed } \\
\text { Learning }\end{array}$ \\
\hline 4 & C\&E & $\begin{array}{l}\text { Computers } \\
\text { Education }\end{array}$ \\
\hline 5 & ETR\&D & $\begin{array}{l}\text { Educational } \\
\text { Technology Research } \\
\text { and Development }\end{array}$ \\
\hline 6 & JNE & $\begin{array}{l}\text { Journal of Nursing } \\
\text { Education }\end{array}$ \\
\hline 7 & JS & $\begin{array}{l}\text { Journal of Sociology } \\
\text { Educational and } \\
\text { Psychological } \\
\text { Measurement }\end{array}$ \\
\hline 9 & EPM & $\begin{array}{l}\text { BMC Medical } \\
\text { Education. }\end{array}$ \\
\hline 10 & BALL & $\begin{array}{l}\text { Computer-Assisted } \\
\text { Language Learning }\end{array}$ \\
\hline
\end{tabular}

This paper examined ten articles from the Scopus database: APE, AJPE, JNE, IJMEST, IREE, PRIMUS, NEP, JPSE, AM, and Tech Trends.

The articles are listed below in tabulation:

\begin{tabular}{|l|l|l|}
\hline SL.NO & Abbreviation & Explanation \\
\hline 1 & APE & $\begin{array}{l}\text { Advances in physiology } \\
\text { education }\end{array}$ \\
\hline 2 & JNE & $\begin{array}{l}\text { Journal of Negro } \\
\text { Education }\end{array}$ \\
\hline 3 & IJMEST & $\begin{array}{l}\text { International Journal of } \\
\text { Mathematical Education } \\
\text { in Science and } \\
\text { Technology }\end{array}$ \\
\hline 4 & IREE & $\begin{array}{l}\text { International Review of } \\
\text { Economics Education }\end{array}$ \\
\hline
\end{tabular}

\begin{tabular}{|c|c|c|}
\hline 5 & PRIMUS & $\begin{array}{l}\text { Problems, Resources, } \\
\text { and Issues in } \\
\text { Mathematics } \\
\text { Undergraduate Studies }\end{array}$ \\
\hline 6 & JPSE & $\begin{array}{l}\text { Journal of Political } \\
\text { Science Education }\end{array}$ \\
\hline 7 & $\mathrm{AM}$ & Academic Medicine. \\
\hline 8 & AJPE & $\begin{array}{l}\text { American Journal of } \\
\text { Pharmaceutical } \\
\text { Education }\end{array}$ \\
\hline 9 & NEP & $\begin{array}{l}\text { Nurse Education in } \\
\text { Practice }\end{array}$ \\
\hline
\end{tabular}

In the year 20137 journals were published, in 20149 journals were published, and 5 journals were published in 2015 .

The judgment or purposive sampling was used in determining the specific participants who have knowledge about the EG and CG.

\subsection{Consideration of this research}

The study was undertaken by informing the participants about the idea, and theme of the study, tools used in this study, the reason for doing this research, and the data of the study. The participants were given the freedom of withdrawing from this at any time, the details given for this were allowed to be taken back at any time. The names of the participants were kept confidentially.

\subsection{Procedures}

The Institute of Engineering Technology courses consist of 3 sections in 3 different classrooms but instructed by the same teachers for about 1 hour $30 \mathrm{sec}$. The students were asked to attend 2 weekly sessions of class. The student's class timing was allocated on a random basis with 2 batches of students learning EG and 1 batch of students to learn CG. All the students learned 4 units during this period. Fig 2 explains the student's allotment for the class. 
Fig.1 Student allotment for class

\begin{tabular}{|l|l|l|l|}
\hline Group & $\begin{array}{l}\text { Student } \\
\text { s }\end{array}$ & $\begin{array}{l}\text { Sections- } \\
\text { Institute of } \\
\text { Engineerin } \\
\text { g } \\
\text { Technolog } \\
\text { y-112 }\end{array}$ & $\begin{array}{l}\text { Assignme } \\
\text { nt }\end{array}$ \\
\hline $\begin{array}{l}\text { Experiment } \\
\text { al } \\
\text { Group(EG) }\end{array}$ & $\begin{array}{l}\text { From 2 } \\
\text { classes }\end{array}$ & $\begin{array}{l}\text { Sections } \\
\text { One \& Two }\end{array}$ & Four units \\
\hline $\begin{array}{l}\text { Control } \\
\text { Group(CG) }\end{array}$ & $\begin{array}{l}\text { From 2 } \\
\text { classes }\end{array}$ & $\begin{array}{l}\text { Section } \\
\text { Three }\end{array}$ & Four units \\
\hline
\end{tabular}

Table.3 Course ( sections and Units) assigned to the EG and CG

\begin{tabular}{|l|l|l|}
\hline Timing & CG & EG \\
\hline Before class & $\begin{array}{l}\text { Online activities } \\
\text { and } \\
\text { assignmemts }\end{array}$ \\
\hline During class & $\begin{array}{l}\text { Traditional } \\
\text { class setup }\end{array}$ & $\begin{array}{l}\text { GD \& in-class } \\
\text { activities. }\end{array}$ \\
\hline After class & $\begin{array}{l}\text { Group activity } \\
\text { \& discussion }\end{array}$ & \\
\hline
\end{tabular}

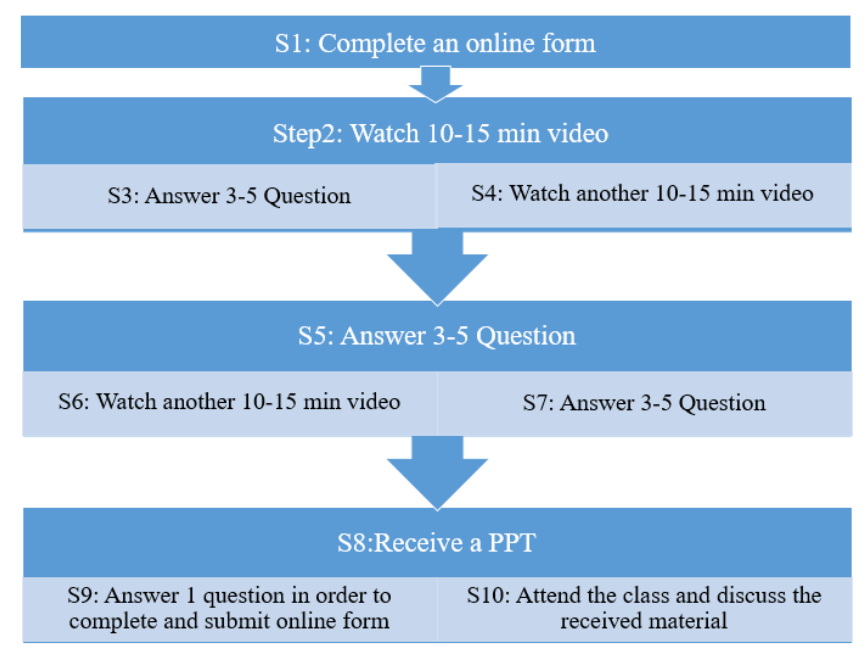

Table.4 The Groups activities(before, during and after class)

\section{Tools and Outcome of the study}

\subsection{Examination Management}

Students were asked to take up 2 exams, the EG \& CG groups were examined of completing both units. The first group completed the first 2 units. The second group completed the 3rd and 4th units.
The end semester exams were based on the topics of all the 4 units of study.

\subsection{Outcomes of the Exam Results}

The resulting outcome was compared between EG\&CG to know the variation of the marks obtained and the learning technique of the students. SPSS was used to know the variation between the 2 groups.

The nature of the t-test is to identify the mean of 2 groups. With the obtained mean the $1^{\text {st }}$ research question was framed:

How the FL helped students in their learning when compared to traditional based learning?

The result of the t-test shows that EG has scored higher than $\mathrm{CG}$ in all the 3 exams. A vast difference was found in the exam results of all the EG. But the final exam result of EG and CG did not show much difference such as in EG Mean (M) was 85.66 and the standard deviation (SD) was 7.71. Whereas in $\mathrm{CG}$ the Mean (M) was 83.79 and the standard deviation (SD) is 7.81.

Table .5 Group Statistics-mean scores after the exam

\begin{tabular}{|c|c|c|c|c|c|}
\hline & Group & $\mathbf{N}$ & $\mathbf{M}$ & SD & $\begin{array}{l}\text { Std. } \\
\text { Erro } \\
\text { r } \\
\text { Mea } \\
\text { n } \\
\end{array}$ \\
\hline & $\begin{array}{l}\text { Experimen } \\
\text { tal Group }\end{array}$ & $\begin{array}{l}12 \\
8\end{array}$ & 8.2500 & $\begin{array}{l}1.2674 \\
0\end{array}$ & $\begin{array}{l}.1120 \\
2\end{array}$ \\
\hline $\begin{array}{l}\text { Exa } \\
\text { m } 1\end{array}$ & $\begin{array}{l}\text { Control } \\
\text { Group }\end{array}$ & 67 & 7.7463 & $\begin{array}{l}1.7696 \\
4\end{array}$ & $\begin{array}{l}.2162 \\
0\end{array}$ \\
\hline & $\begin{array}{l}\text { Experimen } \\
\text { tal Group }\end{array}$ & $\begin{array}{l}12 \\
8\end{array}$ & 7.9766 & $\begin{array}{l}1.6527 \\
9\end{array}$ & $\begin{array}{l}.1771 \\
1\end{array}$ \\
\hline $\begin{array}{l}\text { Exa } \\
\text { m } 2\end{array}$ & $\begin{array}{l}\text { Control } \\
\text { Group }\end{array}$ & 67 & 7.4776 & $\begin{array}{l}1.4497 \\
5 \\
\end{array}$ & $\begin{array}{l}.4032 \\
2\end{array}$ \\
\hline & $\begin{array}{l}\text { Experimen } \\
\text { tal Group }\end{array}$ & $\begin{array}{l}12 \\
8\end{array}$ & $\begin{array}{l}39.417 \\
9\end{array}$ & $\begin{array}{l}4.6204 \\
1\end{array}$ & $\begin{array}{l}.8456 \\
6\end{array}$ \\
\hline $\begin{array}{l}\text { Fina } \\
1 \\
\text { exa } \\
m\end{array}$ & $\begin{array}{l}\text { Control } \\
\text { Group }\end{array}$ & 67 & $\begin{array}{l}36.417 \\
6\end{array}$ & $\begin{array}{l}6.6221 \\
6\end{array}$ & $\begin{array}{l}.6478 \\
8\end{array}$ \\
\hline & $\begin{array}{l}\text { Experimen } \\
\text { tal Group }\end{array}$ & $\begin{array}{l}12 \\
8\end{array}$ & $\begin{array}{l}85.660 \\
2\end{array}$ & $\begin{array}{l}7.7095 \\
2\end{array}$ & $\begin{array}{l}.5647 \\
7 \\
\end{array}$ \\
\hline $\begin{array}{l}\text { Fina } \\
1 \\
\text { grad } \\
\mathrm{e}\end{array}$ & $\begin{array}{l}\text { Control } \\
\text { Group }\end{array}$ & 67 & $\begin{array}{l}83.791 \\
0\end{array}$ & $\begin{array}{l}7.8074 \\
1\end{array}$ & $\begin{array}{l}.4657 \\
7\end{array}$ \\
\hline
\end{tabular}


Table .6 IST

\begin{tabular}{|c|c|c|c|c|c|c|c|c|c|c|}
\hline & \multicolumn{2}{|c|}{$\begin{array}{l}\text { Levene's } \\
\text { test for } \\
\text { equality of } \\
\text { variances }\end{array}$} & \multicolumn{7}{|c|}{ t-Test for Equality of means } \\
\hline & & \multirow[t]{2}{*}{$F$} & \multirow[t]{2}{*}{ Sig } & \multirow[t]{2}{*}{$t$} & \multirow[t]{2}{*}{$\mathrm{df}$} & \multirow[t]{2}{*}{$\begin{array}{l}\text { Sig(2- } \\
\text { tailed })\end{array}$} & \multirow[t]{2}{*}{$\begin{array}{l}\text { Mean } \\
\text { Difference }\end{array}$} & \multirow[t]{2}{*}{\begin{tabular}{|l} 
Std Error \\
Difference
\end{tabular}} & \multicolumn{2}{|c|}{$\begin{array}{l}95 \% \text { confidence } \\
\text { interval of the } \\
\text { difference }\end{array}$} \\
\hline & & & & & & & & & Lower & Upper \\
\hline & $\begin{array}{l}\text { Equal } \\
\text { variances } \\
\text { assumed }\end{array}$ & 3.741 & .064 & 2.290 & 193 & .023 & 57737 & .21966 & .06689 & .98567 \\
\hline \multirow[t]{2}{*}{$\begin{array}{l}\text { Exam } \\
1\end{array}$} & $\begin{array}{l}\text { Equal } \\
\text { variances } \\
\text { not } \\
\text { assumed }\end{array}$ & & & 2.290 & 363 & .041 & 50899 & .24445 & .02468 & .98666 \\
\hline & $\begin{array}{l}\text { Equal } \\
\text { variances } \\
\text { assumed }\end{array}$ & .007 & .933 & 2.086 & 193 & .038 & 68777 & .32456 & .06788 & .97468 \\
\hline \multirow[t]{2}{*}{$\begin{array}{l}\text { Exam } \\
2\end{array}$} & $\begin{array}{l}\text { Equal } \\
\text { variances } \\
\text { not } \\
\text { assumed }\end{array}$ & & & 2.1731 & 219 & .031 & 4.8898 & .56863 & .04513 & .97868 \\
\hline & $\begin{array}{l}\text { Equal } \\
\text { variances } \\
\text { assumed }\end{array}$ & 2.788 & 097 & 3.274 & 193 & .001 & 2.8778 & .98667 & 1.02777 & 4.34678 \\
\hline \multirow[t]{2}{*}{$\begin{array}{l}\text { Exam } \\
3\end{array}$} & $\begin{array}{l}\text { Equal } \\
\text { variances } \\
\text { not } \\
\text { assumed }\end{array}$ & & & 2.935 & 145 & .004 & 3.8787 & .56788 & .06727 & 4.67698 \\
\hline & $\begin{array}{l}\text { Equal } \\
\text { variances } \\
\text { assumed }\end{array}$ & 031 & .859 & 1.061 & 234 & .111 & 3.3323 & 1.16759 & $-43377-$ & 4.25367 \\
\hline $\begin{array}{l}\text { Exam } \\
4\end{array}$ & $\begin{array}{l}\text { Equal } \\
\text { variances } \\
\text { not } \\
\text { assumed }\end{array}$ & & & 1.591 & 113 & .113 & 1.6887 & 1.17224 & $-44959-$ & 4.36789 \\
\hline
\end{tabular}




\section{Findings and Discussion}

The result of this study was done with Journals published in the years of 2013to2015 which was taken from 20 articles. This study focused on the data, instruments used for research, keywords, the impact of FL. The outcomes are detailed:

The various research methodologies were involved in this FL Research. The routinely used methods of FL were found out. The quantitative \& qualitative sampling methods are used often in FL research. This study used several tools to collect liberal information based on effective FL practices [8-17]. The tools used in data collection are experiments, questioning, documentation, and conference meeting. For example, (White, H., \& Sabarwal, S. (2014)) used both survey or census, and open-end type questions to collect data for research [18] collected data through surveys, interviews, trainers, contemplation, and documents. The quantitative method was frequently used in FL classroom research to understand its effectiveness and student's perception through the survey.

The quantitative methodology had been used by various researchers in the FL classroom research [19-26,37]. (Wilson, S. G. (2013) [30]) used testing to understand the difference in learning between FL and instructional Classrooms. (McCallum, (2015);Murray et al (2015) [31-33]) used the census method in understanding about FL and traditional teaching by the end of the course. Figure $2 \&$ Figure 3 shows the \% of FL research from twenty journals published between 20132015.

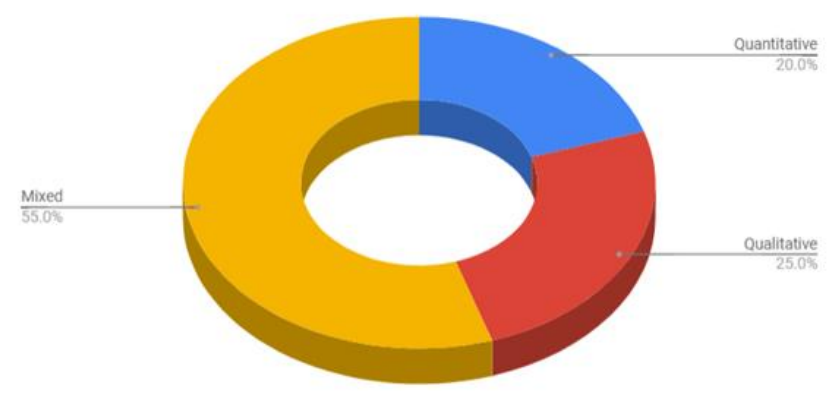

$\%$ of FL research from twenty journals published between 2013-2015.

\section{Fig.2 Percentage of Research Methods}

From the result, it is cleared that 5 publications used both quantitative and qualitative methods, 3 publications used quantitatively in the year 2013. In the year 2014, 5 publications used both the method, 3 used only the quantitative method. Figure 3 explains the often used research methods in the years 2013-2015.

This study involves students from different departments.Most of them were from UG or $1^{\text {st }}$ year students (for example Graduate students were the second most participant [2-10]. The third was college students with no clear knowledge of whether they were undergraduates or graduates.

Nguyen, B et al (2016); Nwosisi et al (2016); Parslow, G. R. (2012) used students from all levels without considering the years and level of their study. Fig 4 illustrates the survey results of the FL study using percentage: surveyed (28) percent; testing (28) percent; interview (14) percent; observation (7) percent; actual test score (5) percent; record analysis (5) percent; and log analysis (2) percent.

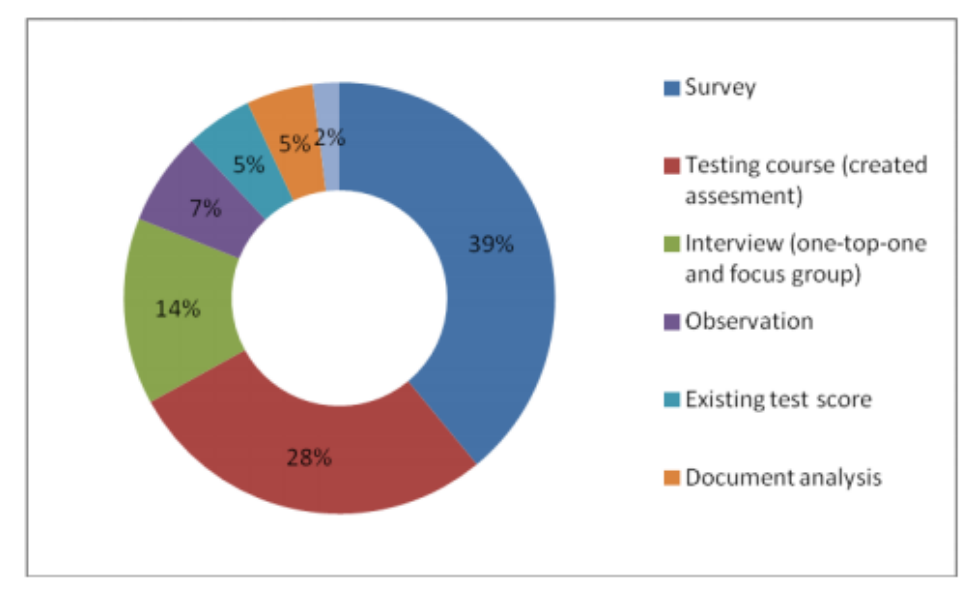

Figure 4. Data collection (instruments).

\section{Conclusion}

In the conclusion, the study of demonstrations has been the major application of cultural activities of flipped learning through the middle to a maximum range of age belongs to the students level. The report analysis of the lectures and students' opinions, learning activities is based on projectbased learning activities and hands-on experience, with the limited time of lectures, students' have faced many problems. The final results has shown that a better understanding of technology using teaching-learning activities has been seen in 
another dimension. The government education system can implement flipped learning for higher education and K12 students. The final discussions were the flipped classroom has been more comfortable and economical space for the students to learn.

\section{REFERENCE}

[1] Touchton, M. (2015). Flipping the classroom and student performance in advanced statistics: Evidence from a quasi-experiment. Journal of Political Science Education, 11(1), 28-44. doi:10.1080/15512169.2014.985105

[2] Wang, S., \& Heffernan, N. (2009). Ethical issues in computer-assisted language learning: Perceptions of teachers and learners. British Journal of Educational Technology, 41(5), 796-813. doi:10.1111/j.14678535.2009.00983.

[3] Lee, K., \& Lai, Y. (2017). Facilitating higherorder thinking with the flipped classroom model: a student teacher's experience in a Hong Kong secondary school. Research and Practice in Technology Enhanced Learning, 2(8), 1-14. https://doi.org/10.1186/s41039-017-00486.

[4] Hattie, J. A. C., \& Donoghue, G. M. (2016). Learning strategies: A synthesis and conceptual model. NPJ Science of Learning, 1, 16013. https://doi.org/10.1038/npjscilearn.2016.13

[5] Fisher, D. (2009). The Use of Instructional Time in the Typical High School Classroom. The Educational Forum, 73(2), 168-176. doi:10.1080/00131720902739650

[6] Fu, J. S. (2013). ICT in education: A critical literature review and its implications. International Journal of Education \& Development using Information \& Communication Technology, 9(1), 112-125

[7] Richter, T., \& McPherson, M. (2012). Open educational resources: Education for the world? Distance Education, 33(2), 201-219. doi: 10.1080/01587919.2012.692068

[8] Evans, D. (2011, October 28). Turning lessons upside down. The Times Educational Supplement, p. 4.

[9] Halili, S. H., Abdul Razak, R., \& Zainuddin, Z. (2014). Enhancing collaborative learning in flipped classroom. Australian Journal of Basic and Applied Sciences, 9(7), 147-149

[10] Johnson, L., Adams Becker, S., Estrada, V., \& Freeman, A. (2014). NMC horizon report: 2014 Higher Education Edition. Austin, Texas: The New Media Consortium.

[11] Creswell, J. W. (2012). Educational research: Planning, conducting, and evaluating quantitative and qualitative research (4rd ed.). Upper Saddle River, NJ: Pearson Education.

[12] Hwang, Gwo-Jen, Chiu-Lin Lai, and SiangYi Wang. "Seamless flipped learning: a mobile technology-enhanced flipped classroom with effective learning strategies." Journal of computers in education 2.4 (2015): 449-473.

[13]Roach, Travis. "Student perceptions toward flipped learning: New methods to increase interaction and active learning in economics." International review of economics education 17 (2014): 74-84.

[14] Karabulut-Ilgu, Aliye, Nadia Jaramillo Cherrez, and Charles T. Jahren. "A systematic review of research on the flipped learning method in engineering education." British Journal of Educational Technology 49.3 (2018): 398-411.

[15] Chen Hsieh, Jun Scott, Wen-Chi Vivian Wu, and Michael W. Marek. "Using the flipped classroom to enhance EFL learning." Computer Assisted Language Learning 30.1-2 (2017): 1-21.

[16]Lo, Chung Kwan, and Khe Foon Hew. "A critical review of flipped classroom challenges in K-12 education: Possible solutions and recommendations for future research." Research and practice in technology enhanced learning 12.1 (2017): 4.

[17] Akçayır, Gökçe, and Murat Akçayır. "The flipped classroom: A review of its advantages and challenges." Computers \& Education 126 (2018): 334-345.

[18]Zainuddin, Zamzami. "Students' learning performance and perceived motivation in gamified instruction." Computers \& education 126 (2018): 75-88. 
[19] Strayer, J. F. (2012). How Learning in an Inverted Classroom Influences Cooperation, Innovation and Task Orientation. Learning Environments Research, 15, 171-193.

[20] Rateau, R. J., Kaufman, E. K., \& Cletzer, D. A. (2015). Innovative classroom strategies that prepare college graduates for workplace success. Journal of Agricultural Education, $56(3)$, $52-68$. https://doi.org/10.5032/jae.2015.03052

[21] Roehl, A., Reddy, S. L., \& Shannon, G. J. (2013). The flipped classroom: An opportunity to engage millennial students through active learning strategies. Journal of Family and Consumer Sciences, 105(2), 4449. https://doi.org/10.14307/JFCS105.2.12

[22] Rosenman, R. V., Tennekoon, L., \& Hill, L. G. (2011). Measuring Bias in Self-Reported Data. International Journal of Behavioural and Healthcare Research, 4(2), 320-332. https://doi.org/10.1504/IJBHR.2011.043414

[23] Sams, A., \& Bergmann, J. (2013). Flip your students' learning. Education Leadership, 70, 16-20.

[24] Schmidt, S. M. P., \& Ralph, D. L. (2016). The Flipped Classroom: A Twist on Teaching Contemporary Issues in Education Research, 9(1), 1-6.

[25] Schultz, D., Duffield, S., Rasmuseen, S. C., \& Wageman, J. (2014). Effects of the flipped classroom model on student performance for advanced placement high school chemistry students. Journal of Chemical Education, 91(9), 1334-1339. https://doi.org/10.1021/ed400868x

[26] Hao, Yungwei. "Exploring undergraduates' perspectives and flipped learning readiness in their flipped classrooms." Computers in Human Behavior 59 (2016): 82-92.

[27] Swapp, D. (2017). Critical Thinking, Active Learning, and the Flipped Classroom: Strategies in Promoting Equity, Inclusion and Social Justice in the B.Ed. Classroom. Teaching Innovation Projects, 7(1), Article 8

[28] Talbert, R. (2014). Inverting the linear algebra classroom. Primus, 24(5), 361-374. https://doi.org/10.1080/10511970.2014.88345
7 Tucker, B. (2012). The flipped classroom. Education Next, 12(1), 82-83.

[29] White, H., \& Sabarwal, S. (2014). Quasiexperimental Design and Methods. Methodological Briefs: Impact Evaluation, 8. UNICEF Office of Research, Florence.

[30] Wilson, S. G. (2013). The Flipped Class: A Method to Address the Challenges of an Undergraduate Statistics Course. Teaching of Psychology, 40, 193-199.

[31] McCallum, S., Schultz, J., Sellke, K., \& Spartz, J. (2015). An Examination of the flipped classroom approach on college student academic involvement. International Journal of Teaching and Learning in Higher Education, 27, 42-55.

[32] McGivney-Burelle, J., \& Xue, F. (2013). Flipping Calculus. Problems, Resources, and Issues in Mathematics Undergraduate Studies, 23, 477-486

[33] Murray, D., Koziniec, T., \& McGill, T. (2015). Student Perceptions of Flipped Learning. In Daryl D'Souza and Katrina Falkner (Eds.), Proceedings of the 17th Australasian Computing Education Conference (ACE 2015). CRPIT. 160. Sydney, Australia: ACS.

[34] Nguyen, B., Yu, X., Japutra, A., \& Chen, C. S. (2016). Reverse teaching: Exploring student perceptions of "flip teaching". Active Learning in Higher Education, 17(1), 51-61.

[35] Nwosisi, C., Ferreira, A., Rosenberg, W., \& Walsh, K. (2016). A Study of the Flipped Classroom and Its Effectiveness in Flipping Thirty Percent of the Course Content. International Journal of Information and Education Technology, 6(5), 348-351. https://doi.org/10.7763/IJIET.2016.V6.712

[36] Parslow, G. R. (2012). Commentary: The Khan Academy and the day-night flipped classroom. Biochemistry and Molecular Biology Education, 40(5), 337-338.

[37]Persky, A. M., \& McLaughlin, J. E. (2017). The Flipped Classroom - From Theory to Practice in Health Professional Education. American Journal of Pharmaceutical Education, $\quad 81(6), \quad 118$. https://doi.org/10.5688/ajpe816118 